\title{
L'HORTA DE VALÈNCIA: PAST AND PRESENT DYNAMICS IN LANDSCAPE CHANGE AND PLANNING
}

\author{
CARME MELO \\ Inter-university Institute for Local Development and Geography Department, University of Valencia, Spain.
}

\begin{abstract}
This paper assesses the evolution in the preservation, management and planning of a cultural landscape: the historical Mediterranean huerta of Valencia, l'Horta de València. After a characterization of l'Horta as a traditional cultural landscape and a description of its main elements and functions, an account of the driving forces behind changes in this landscape is offered. This account highlights the way in which shared patterns of landscape transformation in Europe materialize in the particular case of l'Horta. It is argued that the negative changes and impacts are not simply the outcome of global dynamics but the result of the region's planning trajectory and approach to landscape management. This has been shaped by the lack of a territorial and supra-municipal perspective and the primacy of aspects related to culture, identity and heritage over the productive dimension of the landscape. This claim unfolds through an overview of the planning and policy background that has determined the fate of l'Horta over the past decades and an analysis of the new planning tools recently adopted by the Valencia regional government, L'Horta Law and the Territorial Action Plan for the Management and Revitalization of L'Horta, both from 2018. The paper reflects on the general approach of these documents in the light of the literature on landscape planning and peri-urban agricultural landscapes and assesses the main differences and similarities with respect to the previous institutional and planning contexts.

Keywords: l'Horta de València, la Huerta de Valencia, Mediterranean huertas, cultural landscapes, peri-urban agriculture, landscape planning, landscape preservation, Valencia
\end{abstract}

\section{INTRODUCTION}

Since the adoption of the European Landscape Convention in 2000 the protection and planning of landscapes has become a matter of growing importance in Europe [1], [2]. The Convention considers a landscape to be "an area, as perceived by people, whose character is a result of the action and interaction of natural and/or human factors" [3]. This concept highlights that "landscape is everywhere" and that "all landscapes matter" [4]. Although recognizing the importance of the holistic approach [5] of the Convention in valuing all landscapes equally -natural and cultural, ordinary, special or degraded- this article focuses on traditional and cultural landscapes. Marc Antrop defines traditional landscapes as those "with a distinct and recognizable structure which reflects clear relations between the composing elements" as well as natural, cultural or aesthetical values [6]. All traditional landscapes are cultural landscapes produced by the interaction between humans and nature over the centuries [7]. These landscapes have "a long history, which evolved slowly and where it took centuries to form a characteristic structure reflecting a harmonious integration of abiotic, biotic and cultural elements" [6]. Hence the concept of landscape "refers both to a material-physical reality, originating from a continuous dynamic interaction between natural processes and human activity, and to the immaterial existential values and symbols of which the landscape is the signifier" [8].

This paper evaluates the evolution in the preservation, management and planning of a cultural landscape: the historical Mediterranean huerta of Valencia, referred to as l'Horta de València in the autochthonous Catalan language. It is based on a critical review of case studies and a document analysis of the new planning instruments. After a characterization of l'Horta as a traditional cultural landscape and a description of its main elements and functions, an 
account of the driving forces behind changes in this landscape is offered. This account highlights the way in which shared patterns of landscape transformation in Europe materialize in the particular case of l'Horta. It is argued that the negative changes and impacts are not simply the outcome of global dynamics but the result of the region's planning trajectory and approach to landscape management. This has been shaped by the lack of a territorial and supra-municipal perspective and the primacy of aspects related to culture, identity and heritage over the productive dimension of the landscape. This claim unfolds through an overview of the planning and policy background that has determined the fate of l'Horta over the past decades and an analysis of the new planning tools recently adopted by the Valencia regional government, L'Horta Law and the Territorial Action Plan for the Management and Revitalization of l'Horta, both from 2018. It should be noted that this is not a technical analysis of these new planning instruments. The paper's intention is to reflect on the general approach of these documents in the light of the literature on landscape planning and peri-urban agricultural landscapes and start assessing the main differences and similarities with respect to the previous institutional and planning contexts. At the time of writing this contribution, the final version of the Plan has not been publicized yet despite having been approved by the Parliament, so the arguments advanced here are based on the draft produced for the public consultation phase. The conclusions incorporate some of the findings of the collective process of analysis of these two instruments undertaken in 2015 by members of the social movement Per l'Horta in collaboration with planning experts, in which the author took part [9].

\section{L'HORTA DE VALÈNCIA, A TRADITIONAL CULTURAL LANDSCAPE}

Huertas are agricultural landscapes located around the city borders. They are among the most distinctive traditional agricultural systems in Europe [10], [11] (Fig. 1). If we accept that landscapes are imbued with a 'sense of place' [12] that shapes local or national identity [13], then l'Horta de València is more than a typically Mediterranean water landscape. It has a well-defined character, deeply connected to local geography, history, politics and culture. Over the last two centuries, l'Horta became an iconic landscape. It has been the landscape most closely related to Valencia in the minds of foreigners as well as in the local social imaginary. The construction of the Valencian identity signs were based on the agrarian iconography of l'Horta [14], [15].

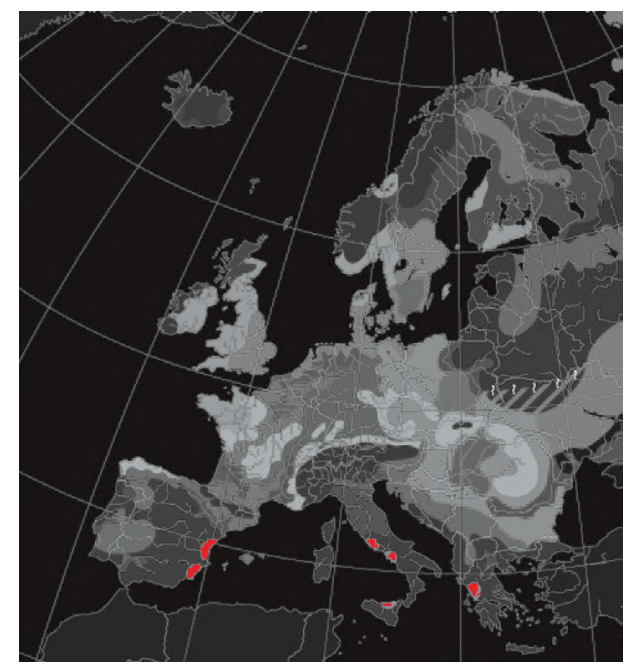

Figure 1: Location of the Mediterranean huerta landscapes [71]. 
L'Horta de València is the irrigated cropland located in the Valencian region, in the metropolitan area of its major city, Valencia. This space includes 44 towns and has a population of over one and a half million. L'Horta is the agricultural peri-urban land irrigated by the Túria river through eight canals. It spreads through the alluvial plain between the Túria river, the Mediterranean sea and the Albufera lake, connecting these water ecosystems (Fig. 2). The most solid hypothesis suggests that it originated in the eighth century, when the Muslims built the water infrastructure: irrigation canals and dams, ditches and hydraulic mills. A productive agricultural space was gradually created; the swamp areas were dried, ancient irrigation and agricultural techniques from the Middle East were introduced and crops common during the Roman period, like cereals, vineyards and olives, were complemented by others such as rice, tiger nut and vegetables [15]-[17]. L'Horta has attracted the attention of prominent scholars interested in its cultural heritage, the Islamic irrigation technology, the communal and selfgoverning institutions and urban-rural relations [18]-[20]. Yet beyond historical testimony, landscapes are socio-ecological subsystems essential for the future sustainability of cities and regions [21]. Pressing problems of today like climate change and food security frame l'Horta as the green infrastructure that provides ecosystem services for the metropolitan area.

The 'material-physical reality' of l'Horta is made up of a complex irrigation system, a network of rural roads, traditional buildings for residential, religious and farming uses such as alqueries and barraques, and a dynamic space of fields and crops that evolved throughout the centuries and still today varies from season to season. The 'immaterial existential values' are related to the traditional agricultural knowledge and techniques, the local varieties of crops and the Medieval communal institutions created to orchestrate social interactions and manage water use, like the irrigation communities for justice and equity in water distribution and the communal Water Tribunal, declared UNESCO World Heritage in 2009. The Tribunal still meets every Thursday at the Gothic portal of the city's cathedral [15], [22], [23].

Landscapes are no longer seen as changing automatically following social transformations. They are independent from us and have essential functions [24]. The case of l'Horta illustrates the key environmental, social and aesthetic functions performed by agriculture in peri-urban landscapes [25]. At the environmental dimension, l'Horta helps preserving biodiversity and water resources, and contributes to the prevention of flooding, climate change adaptation and mitigation. It is vital for climate improvement, allowing sea-breeze circulations and carbon capture. At the territorial level, l'Horta is a green infrastructure which acts

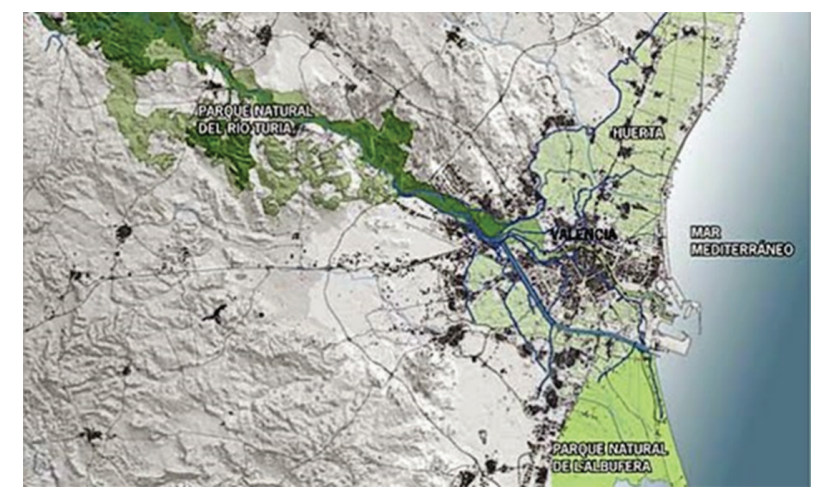

Figure 2: L'Horta connects the most important ecosystems of the metropolitan area, the river Túria natural parc, the Albufera lake and natural parc and the Mediterranean Sea (Source: Generalitat Valenciana). 
as a barrier against urban sprawl and connects the natural spaces in the metropolitan area [26], [27]. As a space for food production, it contributes to food security, food sovereignty and food justice within a regional food supply chain based on its proximity to the city. In addition, peri-urban farmland is also appreciated from a recreational and leisure perspective and this has been documented in the case of l'Horta [28]. The importance of l'Horta for society lies in the combination of these elements: the physical material heritage, the cultural and historical dimension and its functional and aesthetic value.

\section{DRIVING FORCES FOR LANDSCAPE CHANGE IN L'HORTA}

Landscapes are not inherited as static entities. They are constantly created, reorganized and managed as agricultural and land-use patterns evolve. Change is, thus, inherent to landscapes [4], [6], [8], [12], [29]. However, traditional landscapes across Europe have undergone rapid and profound transformations in the 20th century [1], [7], [24], [30]. Land-use changes triggered the expansion of cities into surrounding rural areas; this took place without planning and control [31]. Modern impacts on traditional landscapes became evident after the economic development that followed World War II. But it was only in the 1990s when awareness of the negative nature of landscape change increased. As intensive agriculture has replaced traditional technologies and techniques, landscapes have become homogeneous. Anthropic intervention compromises natural processes and has important consequences for biodiversity [30]. These transformations are perceived as a threat to landscape diversity, coherence and identity.

Much has been written on negative changes in traditional and cultural landscapes [32]-[37]. These studies identify the causes behind the reduction of traditional cultural landscapes, namely land abandonment, agricultural intensification, afforestation, urbanization, increase of infrastructures, population growth and changes in lifestyles. A review of the literature on traditional agricultural landscapes in Spain also reveals shared patterns, despite differences concerning the proximity to urban centers and touristic areas as well as accessibility. These patterns are a decrease of productive activities, the emergence of other land uses (especially infrastructures and urban amenities), changes in traditional crops, the deterioration of built heritage and a general neglect of landscape value and management [38]-[41]. Following Antrop [12], the main driving forces of landscape negative change can be synthesized in three interrelated phenomena: accessibility, urbanization and globalization. These adverse forces are behind the deterioration of l'Horta too. Drawing on a literature review of case studies of l'Horta, this section shows how these three drivers for landscape change combine with the particular natural conditions and local context.

Valencia evolved in symbiosis with its surrounding Horta. L'Horta sustained the city's economy while the city provided the markets and investment needed to sustain the productive system. An accelerated process of industrialization began in the 1950s. This created a dynamic of social change that brought about population growth and urbanization. The city grew and absorbed the surrounding towns and a space of irrigated cropland turned into a metropolitan area. Tourism and industry became the most important productive sectors, replacing agriculture. Farmland was abandoned and other land uses emerged, such as industrial and residential. In 1956, 81.5\% of the city's surface was farmland; by 1991, agriculture represented less than $13 \%$ [15]. This put l'Horta in a situation of neglect and deterioration that was even worsened at the turn of the 21 st century, when the real estate industry became the key driver of the economy.

Rapid and unregulated urban expansion has led to the domination of the city over l'Horta and the triumph of modernity over tradition [42]. Its condition of peri-urban agricultural matrix and proximity to the city center has triggered a decrease in the cultivated surface of 
the traditional Horta. Irrigation canals have reduced their irrigation perimeter and the surface of irrigated land has decreased notably since the 1950s [43]. While l'Horta had 7350 hectares in 1863, by 2003 only 3.394 hectares remained [44]. Research assessing spatial changes between 2008 and 2013 identifies a decrease of $6.5 \%$ in the cultivated area [45]. The authors conclude that land abandonment is the main reason explaining such decrease.

The most significant landscape changes took place in the 1960s and 1970s. The Túria river diversion and the enlargement of the port were carried out in this period, as well as the development of infrastructure such as motorways, ring roads, railways, treatment plants and industrial areas. Yet the construction of infrastructures continued throughout the 1990s, reducing even more the productive space of l'Horta and increasing land fragmentation [46]. Examples of this are the construction of the A-7 highway along the Mediterranean coast, the high-speed railway (AVE) and roads to access the city. This trend goes on. New infrastructures with a high territorial impact are currently being projected, such as the extension of metropolitan roads, the new northern access to the port and the additional platform for the high-speed train. These interventions are likely to further land fragmentation, the use of private vehicles and ecological risks. One of the most controversial projects is the plan proposed by the autonomous Port Authority to develop a zone of logistical activities (or ZAL) for container handling in the town of La Punta, located in l'Horta landscape. The project was first announced in 1993. A conflict was soon set in motion, involving public authorities, neighbours, citizen organizations and public opinion. Despite opposition and protests, the process of forced expropriation began in 1998. Human rights abuses were justified by the government as necessary to create a logistics area that would expand the port and economic opportunities for the region [15]. But the truth is that such space was never finished and remains unused to date. The public administrations involved are seeking to re-activate and conclude the plan. This will place an industrial and logistics area in one of the most strategic parts of the green infrastructure.

The ecological impacts of urban dynamics are strongly perceived in l'Horta. Irrigation canals are used as drains or dumping sites for wastewater [46]. The salinization of farmland, the decrease of water quality and the contamination of underground waters are issues of major concern [28]. The modernization of irrigation networks has damaged the hydraulic heritage and has produced serious environmental problems, especially a decrease in water quality and changes in the levels of salts [38], [47].

The evolution of global agro-food patterns has had remarkable effects on the productive activities and relations in l'Horta. Agricultural production has decreased while small-scale farming has been replaced by industrial and mechanized agriculture [47]. Agricultural landuse patterns have evolved. Cereals, olives, vineyards, sugarcane and mulberries were cultivated in the past. Demographic growth explains the introduction of horticultural agriculture and the subsequent expansion of oranges. Today the predominant crops are horticultural varieties, citrus, rice and ornamental plants [46]. Abandoned land and new land uses, including recreational activities, gardening and self-production, are replacing what once was cultivated-for-profit land. The scarce profitability of crops, insecurity, vandalism episodes, the vulnerability of aged land owners and the difficulties they are facing to pass land-use rights onto next generations are compromising the social and economic sustainability of agriculture. In addition, local products have to compete with other types of production that do now have better access to urban markets. Traditional farming in l'Horta has suffered the consequences of the globalization and industrialization of productive processes experienced elsewhere in Europe.

The preservation of cultural and natural heritage includes the maintenance of landscapes [8]. A number of institutions are working worldwide to achieve this end, for example, the UNESCO World Heritage Center and the Council of Europe, as well as many international civil society 
organizations. The European Landscape Convention [3] conceives landscapes as Europe's common heritage and urges their special protection and management. In spite of this, there has been a general lack of interest in the conservation of the built cultural and natural heritage of l'Horta, such as the historical irrigation networks and other elements of the architectonic heritage.

\section{THE PROTECTION, MANAGEMENT AND PLANNING OF L'HORTA: PAST TRENDS}

At this point, the claim made at the introduction of this paper should be elaborated: that the negative changes and impacts of human activities on l'Horta - illustrated in the previous section - are not just the result of global dynamics related to urbanization, globalization and accessibility, which affect virtually all European traditional cultural landscapes, but the consequence of the region's planning trajectory. This claim will be further developed in the next section.

The protection, management and planning of cultural landscapes, like l'Horta, is one of the key pillars of the European territorial approach [49]. This approach is based on territorial governance to achieve sustainable territorial development. From this perspective, new elements are introduced in territorial politics and policy, specifically those related to the emergence of new forms of governance, environmental sustainability and social cohesion. Territory is conceived in a broader sense, that is, as social product, resource, heritage, landscape, public good and space for solidarity. This model no longer gives priority to economic growth and resource consumption; it also seeks to achieve sustainable development and equity at the intra and intergenerational levels. Various national and international initiatives along these lines could be mentioned, such as the European Landscape Convention [2], [3], the Opinion of the European Economic and Social Committee on Agriculture in Peri-urban Areas [50], the Charter on Peri-urban Agriculture [51] and the Spanish legislation on sustainable rural development, especially the 2007 Law for Rural Sustainable Development. Yet the principles informing the territorial approach have not been adequately developed into policy in Spain, where territorial planning has been subordinated to economic growth and sectoral politics. In addition, territorial planning varies across the different regions and the central government has not assumed coordination tasks. Consequently, each government ministry and regional administration has advanced its particular view [52].

In order to understand the present state of affairs it is important to explain the institutional background that has framed policies concerning l'Horta for the past two decades. The conservative Partido Popular ruled the region and the city of Valencia for more than 20 years. In this period, there were no planning and management tools at the metropolitan scale. There was an attempt to adopt such approach through the creation of a metropolitan council in 1988. Ten years later, in 1999, the council disappeared due to conflicts over land-uses between the different municipalities and the metropolitan entity. Between 1997 and 2007, during the real estate boom, municipalities strongly opposed attempts to orchestrate coordination at the metropolitan level. Each had its own agenda to promote urban development as an important source of tax revenue [17]. There was no political will in municipal and regional governments to protect l'Horta [15].

In these decades land-use policy was based on privatization and liberalization. Legislation was unclear and non-binding, while urban and territorial planning encouraged urbanization and land speculation. This resulted in the fragmentation of the territory and the disconnection between l'Horta and the city [53], [54]. Residential expansion, logistics and transport infrastructures were the key productive activities. In many cases, these took place at l'Horta expense in a context in which corrupt planning was commonplace. The price of land was constantly rising due to speculation, so land owners had good reasons to sell their land for 
construction purposes, instead of continuing with small-scaled agricultural activities that had low profitability [17]. These changes were the consequence of the neoliberal urban model adopted. This model viewed the real estate industry and the making and unmaking of the city as the main drivers for economic growth [53]. In this scenario, l'Horta was seen as mere land for urban development. This were the most critical times for l'Horta, the 1990s and the first decade of the 21st century, when the neoliberal urban policy approach threatened its survival.

All this happened while public authorities constructed a discourse in which farmers and farming activities were seen as keeping the region backwards. In this discourse, economic growth and global competitiveness demanded that Valencia left its agricultural identity behind and pushed for other productive sectors, especially urban projects, mega-events and tourism [14]. A process of landscape reorientation and displacement took place: l'Horta was crowded out, both geographically and symbolically, by new ideological landscapes of global competitiveness, modernity and cultural innovation, such as the City of the Arts and Sciences, projected amongst what were ancient croplands [15].

Civil society organizations confronted public institutions and showed a greater concern for cultural and agricultural landscapes. The value of l'Horta as historical, cultural, natural and agricultural heritage and the need to prevent further damage informed the 2000 Opinion of the Valencia Council of Culture, a consultation and advisory body for the regional government. But its advice never came to inform policy. In 2001 a citizen movement wrote the first Popular Legislative Initiative in Valencia, which demanded the adoption of a law regulating the planning and protection of l'Horta. Despite having achieved twice as much the number of signatures required within less than four months, it was rejected by the regional Parliament. All political parties supported the initiative, except Partido Popular, which held the majority [15], [17].

Since then, citizens' awareness and popular resistance movements concerning land have grown. Probably as a result of such concern and mobilization, the regional government stipulated that a protection plan should be designed: the Territorial Action Plan for the Protection of l'Horta de València, announced in 2008 [17], [26]. The Plan was an attempt to protect the most valuable elements of l'Horta landscape that still remained, especially its architectural heritage and cultural aspects, after decades of abandonment and degradation. It was necessary to safeguard what was still farming land at a time when it was seriously jeopardized by urban sprawl and the real estate boom. This seemingly good intention was counterproductive. Institutional approaches to l'Horta at this time were overly focused on landscape preservation. This perspective neglected the importance of productive farming activities [55]. L'Horta is the result of socio-natural relations embodied in agriculture and the transformation of land for farming uses. So if the productive functions of l'Horta are not sustained, the continuity of l'Horta is not guaranteed [54]. Furthermore, the Plan lacked mechanisms to avoid future conversion of rural land to urban use and to halt the growth-based aspirations of municipal master plans [56]. Anyhow, the Plan was discarded in 2010 and never evolved into binding regulations (until the public administration that took over from the conservatives in 2015 gave a new impetus to it, as I will illustrate). Several reasons could explain this failure. While the document was being drafted, other regional and national ministries with decision-making competences on l'Horta adopted different types of policies and authorized the construction of infrastructure not coherent with the Plan's guidelines. Moreover, the municipalities did not want to lose autonomy in land-use management. It is worth recalling that the government's reluctance to adopt instruments for the protection and management of l'Horta (exemplified by the failure of the Popular Legislative Initiative and the Territorial Action Plan) was followed by an acute period of land speculation and construction [15]. 
The last example of bad management and lack of appropriate protection policies for l'Horta during the conservative government is the revision of the General Land-Use Plan of the city of Valencia, initiated in December 2014. The draft established the reduction of 415 hectares of l'Horta surface to allow the construction of new 17,000 housing units and other infrastructures. The project did not succeed because of the massive public reaction, with NGO's campaigns and citizen protests taking place in the subsequent months. Civil society organizations filed over 20,000 submissions during the public information period to express their opposition to the loss of traditional Horta. Even the Water Tribunal filed a submission expressing its concern for the integrity of the irrigation canals. A greater sensibility was evident in the media too [57]-[60]. This public pressure and civic participation was not in vain. In May 2015 the regional government announced the withdrawal of the reform. This was an important victory for citizens, social movements and l'Horta.

The events illustrated in this section suggest that the main problem concerning the management and planning of l'Horta has been the absence of political will of regional and municipal governments. They have not been committed enough so as to sponsor metropolitan territorial or sectorial plans and imagine new management tools, good governance mechanisms and different territorial and landscape functions for l'Horta and their farmers. For over a decade, legal provisions to protect cultural landscapes in Spain, like l'Horta, coexisted with an expansive economic phase in which land was simply a market-exchange good. There was no cooperation between public authorities and citizens in the realm of space planning. Instead, economic actors where the most powerful agents of land transformation and became the most influential planning and urban policy actors [53].

\section{NEW PLANNING INSTRUMENTS FOR L'HORTA LANDSCAPE: L'HORTA LAW AND THE TERRITORIAL ACTION PLAN FOR THE MANAGEMENT AND REVITALIZATION OF L'HORTA}

The May 2015 elections meant the victory of a coalition of left-wing governments at the local and regional levels. This signalled a turning point towards a more participatory approach to policy-making, one that is more sensitive to issues concerning territorial planning. After decades of land speculation and lack of adequate planning and management, l'Horta plays a central role in the new territorial approach and the new productive model upheld by the present regional administration. The progressive government coalition, so called "government of change", has proclaimed its will to break with the previous territorial model, earlier explained. This is being sought, mainly, through a two-fold strategy that includes the green infrastructure, a concept already introduced by 2011 Territorial Strategy of the Valencia region, and a redefinition of the region's productive model in a way that recognizes the value of agriculture.

In line with this spirit, two policy tools with an impact on l'Horta have been designed: L'Horta Law [61] and the Territorial Action Plan for the Planning and Revitalization of l'Horta [62] (Fig. 3). These are the first planning instruments ever adopted for the specific protection and management of l'Horta landscape. They are the result of the demands of citizens and civil society organizations who have long mobilized to stop land abuses and related human rights violations.

Fifteen years after the first Popular Legislative Initiative that demanded a specific law for the protection of l'Horta, this was passed in March 2018. L'Horta Law defines l'Horta as a green belt that prevents the future growth of the metropolitan area and expands the surface to be protected from urban development. To achieve its objectives, three instruments are to be further developed: the Territorial Action Plan - to which I will return - the Agrarian Development Plan and a governance institution, the Horta Council. Farming activities and food 


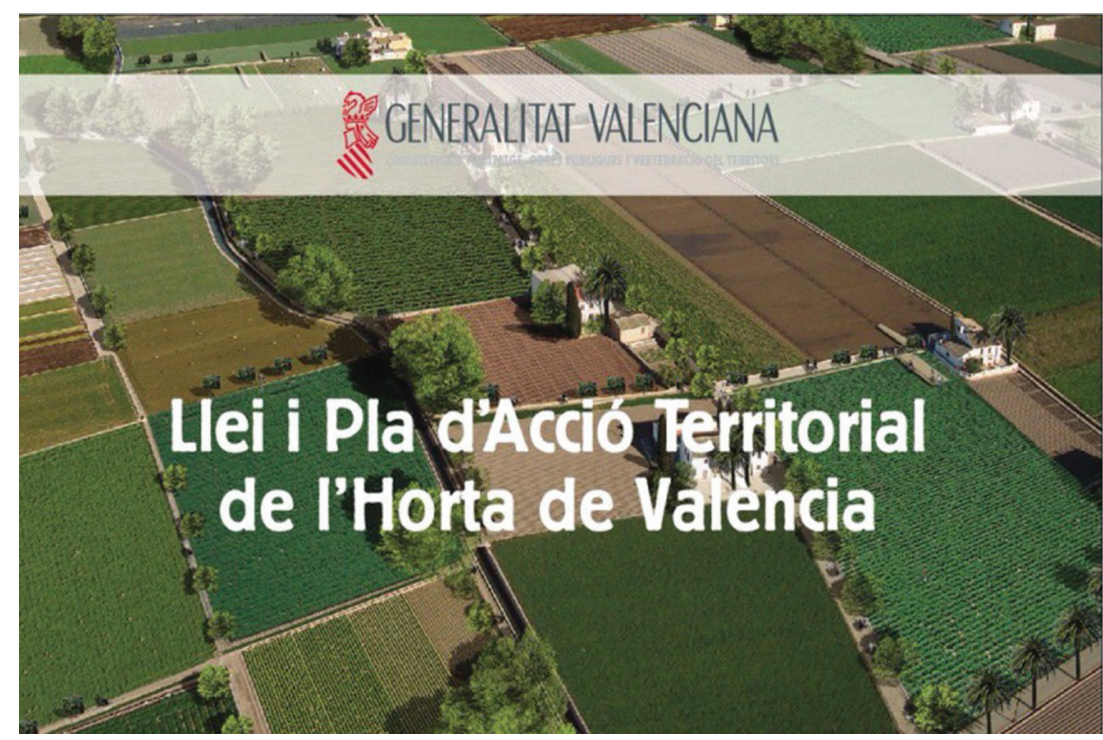

Figure 3: Aerial view of 1'Horta used by the regional administration to announce L'Horta Law and the Territorial Action Plan (Source: Generalitat Valenciana).

production functions are prioritized over other land uses, following longstanding demands of farmers and environmental and land activists that see the sustainability and viability of agricultural activities as necessary for the survival of l'Horta. In this sense, the Law is aligned with some of the most recent trends in landscape planning.

Landscape planning has traditionally aimed at the preservation of traditional cultural landscapes. Throughout the 20th century landscapes were mostly treated as spaces to be enclosed and protected as cultural heritage or sanctuaries of biodiversity. The European Landscape Convention has brought about significant transformations in the perceptions and management of cultural European landscapes. The Convention adopts a 'forward-looking' approach based on the enhancement, restoration and creation of landscapes. From this perspective, landscape policy has to accept landscape change instead of attempting to preserve a nostalgic past and create a balance between protection, planning and management. This includes the reconnection of social-ecological systems and the suppression of strict boundaries between urban and rural so that nature and agriculture go across cities through the green infrastructure [4]. L'Horta Law seeks to create a balance between protection and planning, following the guidelines included in the Landscape Convention on this matter.

The urbanization of l'Horta over the past few decades and the different problems this has created, as indicated in Section 2, happened not only because this is an agricultural space but mainly because of its condition of peri-urban area. In peri-urban spaces a combination of urban and rural land uses originates a new type of landscape which is neither rural not urban [31]. This in-between position renders peri-urban agricultural spaces most vulnerable. Their diffused limits are always under pressure and are the object of opposing demands and interests. They have been urbanized more than any other surface in Europe between 1990 and 2000 [63]. However, peri-urban spaces are crucial in terms of, on the one hand, climate change mitigation and adaptation and, on the other hand, food sovereignty and security in metropolitan areas. This is acknowledged in the European Charter 
of Peri-Urban Agriculture and the Opinion of the European Economic and Social Committee on Agriculture in Peri-urban Areas. Although not included in the first draft, after the amendments made as a result of the public consultation stage, the final version includes the concept of peri-urban agriculture and recognizes the vulnerabilities and potentials of l'Horta as a peri-urban space.

However, the Law does not respond to environmental drivers satisfactorily. In the face of climate change, farming practices in l'Horta should aim at food sovereignty and organic agriculture. Yet the Law fails to bring to an end unsustainable farming as it does not back forcefully a different agricultural model based on a just and local food system. It is true that the Law establishes that an Agrarian Development Plan shall be adopted and that this document includes more specific measures regards how to promote agricultural activity and facilitate the transition towards a more economically and environmentally sustainable local food system. However, the Law could have been the right place to express the guidelines to be followed.

The post-2015 regional government has clearly shown a more participatory and consensual view of politics than its predecessor. It is then surprising that citizen participation is not properly addressed in the policy tools being developed for the protection of l'Horta. As established in the 1998 Aarhus Convention (Convention on Access to Information, Public Participation in Decision-Making and Access to Justice in Environmental Matters, adopted in the United Nations Economic Commission for Europe framework), environmental rights have three pillars: access to information, public participation in decision-making and access to justice. The Law mentions the first pillar, that is, the right to be informed about plans and legislation with an impact in l'Horta, but omits the other two. This omission contravenes the Aarhus Convention and leaves citizens unprotected in case of forced evictions and other abuses perpetrated by public administrations.

As noted earlier, L'Horta Law stipulates that a Territorial Action Plan be adopted to define the green infrastructure, regulate land uses and activities, protect farming land and revitalize agriculture. This is a sub-regional planning tool with a metropolitan scale. It is a revised version of a previous draft, first developed in 2008 and modified in 2010, which was not finalized, as I explain in Section 3. The plan is the result of a long process of public participation. Most problems earlier discussed in this paper are acknowledged and an attempt is made to provide instruments and actions to tackle them. Among these, it is most significant that l'Horta is defined as the key element that makes possible the ecological connectivity of all natural areas included in the green infrastructure of the metropolitan area, which is clearly identified by the Plan (Fig. 4). The aim is to sustain ecological and functional corridors, avoid further fragmentation and facilitate environmental goods and services. A further important point is that 11,000 hectares of Horta are protected as rural land which cannot be developed. In addition, 1500 hectares of land that was already included in development plans projected by some of the municipalities are rescued and converted into rural land. This clearly illustrates the regional government's will to adopt supra-municipal planning and a territorial approach.

Peri-urban cultural landscapes offer multiple goods and services to nearby urban areas, including the provision of ecosystem services, flood control, moderation of urban climate and carbon sequestration [64]. This highlights the importance of the multifunctional approach to farming and agriculture, on the basis of sustainable land-use. According to this approach, landscape policy and planning should integrate the different functions performed by peri-urban farmland. The plan recognizes these environmental and climate-related functions l'Horta plays, incorporating debates on the multifunctionality of agriculture in peri-urban areas [1], [24], [28], [65]-[67].

What is more, the plan is clearly aligned with other guidelines and recommendations suggested in the literature on planning and protection of peri-urban agricultural spaces [41], 


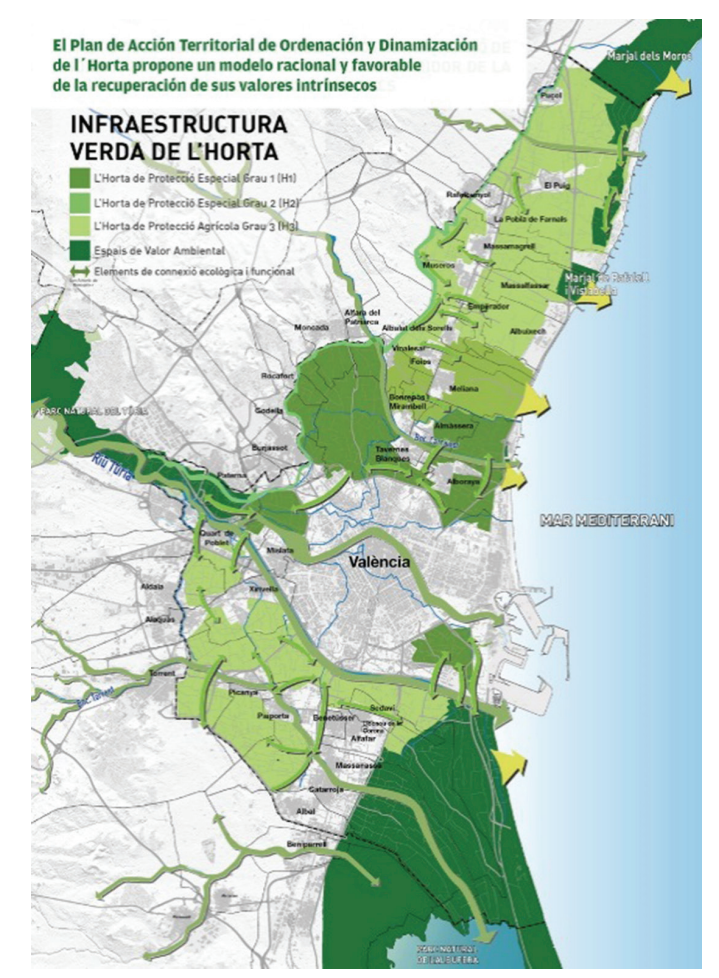

Figure 4: Map of the Green Infrastructure identified by the plan (Source: Generalitat Valenciana).

[68]-[70]. These can be summarized as follows: the development of an agro-environmental plan or programme to guarantee the maintenance of agricultural activities; a strategy to promote the provision of organic, local and healthy food; actions to protect traditional elements of the rural system; the improvement and restoration of degraded landscapes; the enhancement of landscape vision through sightseeing routs, visitors' interpretation and information programmes and the creation of a visitors' centre; and the promotion of public participation in planning. The plan provides specific actions and strategies dealing with all these issues in the particular context of l'Horta. This is a significant change of orientation in relation to the planning and management of this space.

Having said that, a few controversial issues should be noted. The first one refers to the acceptance of tertiary uses and new economic activities intended to complement farmers' income. This includes restaurants, hotels and riding centres, among others. Although the plan indicates that they will have to be compatible with farming, this is a very loose requirement that will leave the door open to the gentrification and touristification of l'Horta. It could be argued that this alternative land uses question the plan's intended objective of achieving the viability of farming by upholding agriculture as the preeminent activity and protecting agricultural land.

Another dubious point is related to the plan's aim of ending urbanization and land speculation. Despite notorious advances with respect to previous management and policy approaches, these new planning tools are still based on a growth ideology. Growth is assumed to be a legitimate aspiration of all municipalities so the protection of l'Horta and the maintenance of farming activities have to coexist with town development plans. These developments will 
take place on areas originally protected by the Plan for being rural land. With the introduction of new planning categories ('enclaves', 'sectors' and 'common rural zones') this protected rural land can be converted into land suitable for development and thus subordinated to town planning. This possibility could be read as a partial victory of municipalities over the regional administration's will to adopt a supra-municipal instrument. In fact, during the Plan's public presentation, government officials recognized that the hardest part of the process was the negotiation with municipalities and that, in order to accommodate their future urban development plans, several concessions had to be made. Only time will tell us how big this victory shall be, depending on how many towns use this possibility and to which extent future urbanization takes place on protected Horta landscape.

Finally, food production functions are given priority over other land uses in both documents, the Law and the Plan. The focus is on increasing productivity, and of course this is a fair demand from the point of view of farmers and a necessary condition for the sustainability of l'Horta. But this objective should not be promoted without taking into account the role l'Horta plays in achieving food sovereignty and food security in the Anthropocene. Its proximity to the city makes peri-urban agricultural areas like l'Horta strategic in achieving a regional food system [64]. Instead, the Law and the Plan seem to encourage a model based on exports and the increase of the region's competitiveness in a global context. This approach could respond once more to the governments' will to accommodate different and sometimes opposing interests, such as those of farmers, land activists and food industries. In short, we find two different and conflicting discourses underlying these two documents: one based on increasing productivity and economic benefits for the food and agriculture sectors, one based on the preservation of the environmental sustainability of l'Horta.

\section{CONCLUSION}

This article has reviewed landscape change dynamics in l'Horta de València. Some of these dynamics are common to other traditional cultural landscapes in Europe. Yet beyond patterns related to urbanization, accessibility and globalization, it has been argued that these changes are the result of the particular regional planning context and approach to landscape management. The institutional background that has informed the preservation, planning and management of l'Horta for decades has been illustrated. This has been characterized by the negligence and lack of political will of public administrations, the absence of territorial planning and management tools at the intermediate level between the regional and the local scale, the neglect of coordination mechanisms at the metropolitan level and a weak territorial culture, all of which placed in a context of disdain of farmers and farming activities.

The trajectory of landscape planning in l'Horta has been evaluated, comparing past and present trends and instruments and assessing them in the light of the literature on landscape planning and peri-urban agriculture. From this analysis, it is possible to conclude that the new instruments adopted in 2018 - L'Horta Law and the Territorial Action Plan - are aligned with the most recent approaches in landscape planning and policy and that they follow the recommendations and guidelines included in case studies on other similar peri-urban agricultural landscapes. They seem to draw on the perspective defined by the European Landscape Convention which combines protection and planning. In this sense, the cultural value of l'Horta is recognized but other important aspects of landscape policy and planning are incorporated too, such as ecosystem services and the green infrastructure. In addition, the new planning instruments surveyed acknowledge the value of agriculture and the importance of farmers and farming activities; this is essential to guarantee the future viability of l'Horta and bring to an end decades of urbanization and land speculation. However, some of the specific tools 
and strategies could create future clashes with these general aims and hence become obstacles to the progress being sought. New planning categories like enclaves, sectors, and rural common zones may have this counterproductive effect. They allow municipalities too much control of town planning, despite significant historical evidence that this has been a tragedy for territorial planning in general and l'Horta landscape in particular in the past.

Landscapes exist everywhere: in rural areas, in urban spaces and in the city margins where rural and urban land collide [4], [5]. This interest in urban and rururban landscapes is very important in the case of l'Horta. It means that those bits of Horta landscape to be found within the city or along the city edges have to be protected as parts of the landscape, even if they are already urbanized or classified as land for future developments or despite being degraded. Although much progress has been made and the amount of protected land has increased notably, L'Horta Law and the Territorial Action Plan do not treat adequately these urban and rururban landscapes. And the projection of infrastructures and future developments provides evidence of this. The conflict around the plan to locate a logistics zone in the port area (or ZAL) earlier mentioned, helps illustrate this point. If the plan is fully executed, an industrial and logistics area will be placed in one of the most fundamental parts of the green infrastructure, one that could be connecting the Túria river and natural parc, the Albufera natural parc and the Mediterranean Sea. Urban interventions like this are amongst the biggest threats to l'Horta. Paradoxically, they are sponsored by those very same public instances that claim to be protecting it. In fact, both the Territorial Action Plan for l'Horta and the special plan intended to conclude and activate the logistics zone were announced by the government the same day, as reported in the local media.

Valencia was elected World Food Capital in 2016. Since then, several strategies and policies have been adopted to promote the transition towards more sustainable and inclusive food systems. In parallel, alternative food networks have spread and developed. A review of such initiatives and their impacts exceeds the scope of this paper. Yet this is an important fact to be mentioned here since efforts to change the agro-food system will be in vain unless farming land is not properly integrated into planning. The sub-regional instruments adopted and analyzed respond to what seems to be a new political will to plan metropolitan areas to create spaces for nature and agriculture. However, challenges persist because l'Horta is still conceived as a commodity. This encourages its tertiarization and jeopardizes farming practices.

\section{REFERENCES}

[1] Barbera, G. \& Cullotta, S., An inventory approach to the assessment of main traditional landscapes in Sicily (Central Mediterranean Basin). Landscape Research, 37(5), pp. 539-569, 2012. https://doi.org/10.1080/01426397.2011.607925

[2] Déjeant-Pons, M., The European landscape convention. Landscape Research, 31(4), pp. 363-384, 2006. https://doi.org/10.1080/01426390601004343

[3] Council of Europe, European Landscape Convention, CoE: Strasbourg, 2000.

[4] Selman, P., The European landscape convention. Rebalancing our approach to landscape? Proceedings of the Latvian Academy of Sciences, Section A, 2012.

[5] Roe, M.H., The European landscape convention: A revolution in thinking about 'cultural landscapes'. Journal of Chinese Landscape Architecture, 23(143), pp. 10-15, 2007.

[6] Antrop, M., The concept of traditional landscapes as a base for landscape evaluation and planning. The Example of Flanders Region. Landscape and Urban Planning, 38(1-2), pp. 105-117, 1997. https://doi.org/10.1016/s0169-2046(97)00027-3

[7] Moreira, F., Queiroz, A.I. \& Aronson, J., Restoration principles applied to cultural landscapes. Journal for Nature Conservation, 14(3-4), pp. 217-224, 2006. https://doi. org/10.1016/j.jnc.2006.05.007 
[8] Antrop, M., Sustainable landscapes: contradiction, fiction or utopia? Landscape and Urban Planning, 75(3-4), pp. 187-197, 2006. https://doi.org/10.1016/j.landurbplan.2005.02.014

[9] Per l'Horta Web Site, Valencia, http://perlHorta.info/index.php/2016/02/26/revisio-critica-del-path-de-valencia/ (accessed 6 December 2018).

[10] Meeus, J.H., Wijermans, M.P. \& Vroom, M.J., Agricultural landscapes in Europe and their transformation. Landscape and Urban Planning, 18(3-4), pp. 289-352, 1990. https://doi.org/10.1016/0169-2046(90)90016-u

[11] Meeus, J.H., Pan-European landscapes. Landscape and Urban Planning, 31(1-3), pp. 57-79, 1995. https://doi.org/10.1016/0169-2046(94)01036-8

[12] Antrop, M., Why landscapes of the past are important for the future. Landscape and Urban Planning, 70(1-2), pp. 21-34, 2005. https://doi.org/10.1016/j.landurbplan.2003.10.002

[13] Sooväli, H., Palang, H. \& Külvik, M., The role of rural landscapes in shaping Estonian national identity. European Landscapes: From Mountain to See. Proceedings of the Permanent European Conference for the Study of Rural Landscape, ed. T. Unwin, London and Aberystwyth, pp. 114-121, 2003.

[14] Santamarina, B. \& Moncusí, A., De huertas y barracas a galaxias faraónicas. Percepciones sociales sobre la mutación de la ciudad de Valencia. Papers, 98(2), pp. 365-391, 2013. https://doi.org/10.5565/rev/papers/v98n2.468

[15] Prytherch, D.L., Elegy to an iconographic place: reconstructing the regionalism/landscape dialectic in L'Horta de València. Cultural Geographies, 16(1), pp. 55-85, 2009. https://doi.org/10.1177/1474474008097980

[16] Guinot, E., La Huerta medieval de Valencia: origen y transformación de un paisaje histórico. La Huerta de Valencia, eds. J. Romero \& M. Francés, PUV: Valencia, pp. 5575, 2012.

[17] i Garcia, J.M., Environmental management of peri-urban natural resources: L'Horta de Valencia case study. WIT Transactions on Ecology and the Environment, 192, pp. 99-110, 2015. https://doi.org/10.2495/eco150101

[18] Glick, T.F., Irrigation and Society in Medieval Valencia, Cambridge University Press: Cambridge, 1970.

[19] Courtot, R., Agriculture irriguée et organisation ou l'espace dans les huertas de Valencia et de Castellon, Université Paris VII: Paris, 1986.

[20] Ostrom, E., Governing the Commons: the Evolution of Institutions for Collective Action, Cambridge University Press: Cambridge, 1990.

[21] Termorshuizen, J.W. \& Opdam, P., Landscape services as a bridge between landscape ecology and sustainable development. Landscape Ecology, 24(8), pp. 1037-1052, 2009. https://doi.org/10.1007/s10980-008-9314-8

[22] Petrella, R., The Water Manifesto, Arguments for a World Water Contract, Zed: London and New York, 2001.

[23] Scovazzi T., Intangible Cultural Heritage as Defined in the 2003 UNESCO Convention. Cultural Heritage and Value Creation, ed. G. Golinelli, Springer: Cham, 2015.

[24] Von Haaren, C., Landscape planning facing the challenge of the development of cultural landscapes. Landscape and Urban Planning, 60(2), pp. 73-80, 2002. https://doi. org/10.1016/s0169-2046(02)00060-9

[25] Davoudi, S. \& Stead, D., Urban-rural relationships. An introduction and brief history. Building and Environment, 28(2), 269-277, 2007. https://doi.org/10.1017/ s0963926801002073 
[26] Muñoz, A., Plan de la Huerta de Valencia. Un paisaje cultural milenario, Valencia: Conselleria de Medi Ambient, Aigua, Urbanisme i Habitatge, 2009.

[27] Carmona, P. \& Ruiz, J.M., El medio físico de l'Horta. El patrimonio hidráulico del bajo Tiria: l'Horta de València, ed. J. Hermosilla, Consellería de Cuñtura y Deporte y Departament de Geografia de la UVEG: Valencia, pp. 30-44, 2007.

[28] Marques-Perez, I., Segura, B. \& Maroto, M., Evaluating the functionality of agricultural systems: social preferences for multifunctional peri-urban agriculture. The "Huerta de Valencia" case study. Spanish Journal of Agricultural Research, 12(4), pp. 889-901, 2014. https://doi.org/10.5424/sjar/2014124-6061

[29] Antrop, M., Continuity and change in landscapes. Landscape change and the urbanization process in Europe. Multifunctional Landscapes, Continuity and Change, Vol. 3, eds. U. Mander \& M. Antrop, WIT Transactions on Ecology and the Environment: Southampton, 2003.

[30] Marignani, M., Rocchini, D., Torri, D., Chiarucci, A. \& Maccherini, S., Planning restoration in a cultural landscape in Italy using an object-based approach and historical analysis. Landscape and Urban Planning, 84(1), pp. 28-37, 2008. https://doi. org/10.1016/j.landurbplan.2007.06.005

[31] Nilsson, K., Pauleit, S., Bell, S., Aalbers, C., \& Nielsen, T.A.S. (eds)., Peri-Urban Futures: Scenarios and Modes for Land Use Change in Europe, Springer: London and NY, 2013.

[32] Mander, Ü., Printsmann, A. \& Palang, H., Development of European Landscapes. Proc. of the Conference of the International Association for Landscape Ecology, European Conference, Vol. 2, Publicationes Instituti Geographici Universitatis Tartuensis: Tartu, p. 804, 2000.

[33] Pedroli, B. (ed), Landscape-Our Home. Lebensraum Landschaft. Essays on the Culture of the European Landscape as a Task, Indigo. Zeist-Freies Geistesleben: Stuttgart, pp. 145-150, 2000.

[34] Klijn, J. \& Vos, W. (eds), From Landscape Ecology to Landscape Science, Kluwer Academic Publishers, WLO: Wageningen, 2000.

[35] Green, B. \& Vos, W. (eds), Threatened Landscapes: Conserving Cultural Environments, Spon Press: London and New York, 2001.

[36] Holdaway, E. \& Smart, G., Landscapes at Risk? The Future for Areas of Outstanding Natural Beauty, Spon Press: London, 2001.

[37] Antrop, M., Landscape change and the urbanization process in Europe. Landscape and Urban Planning, 67(1-4), pp. 9-26, 2004. https://doi.org/10.1016/s0169-2046(03)00026-4

[38] Olmo, R.M. \& Muñoz, S.F., Paisajes y patrimonios culturales del agua. La salvaguarda del valor patrimonial de los regadíos tradicionales. Scripta Nova, 14(337), pp. 1-9, 2010.

[39] Molinero, F. (ed), Atlas de los paisajes agrarios de España, Ministerio de Agricultura, Alimentación y Medio Ambiente: Madrid, 2013-2014.

[40] Ciriquián, P.M. \& Vicente, E.M., La transformación urbana y territorial de la ciudad de Murcia y su entorno (1977-2010). Estudios Geográficos, 75(276), pp. 261-309, 2014. https://doi.org/10.3989/estgeogr.201407

[41] Olmo, R.M. \& Muñoz, S.F., La Huerta de Murcia: landscape guidelines for a peri-urban territory. Landscape Research, 29(4), pp. 385-397, 2004. https://doi. org/10.1080/0142639042000289028

[42] Cárcel-García, C., Verdejo, P. \& Clemente, D., Molino de Llovera, patrimonio de la arquitectura tradicional de la Huerta de Valencia. Irrigation, Society and Landscape. Tribute to Thomas F. Glick, eds. C. Sanchis-Ibor, G. Palau-Salvador, I. Mangue \& L.P. Martínez-Sanmartín, UPV: Valencia, pp. 1171-1186, 2014. 
[43] Marco, J.B., Las redes de regadío de l'Horta y el sistema de recursos hídricos del Turia frente al problema de la subsistencia de l'Horta de Valencia. La Huerta de Valencia, eds. J. Romero \& M. Francés, PUV: Valencia, pp. 113-135, 2012.

[44] Sanchis, C., Les terres de l'Horta de València. Crònica de la recent reducción superficial del regadiu històric. Afers. Fulls de recerca i pensament, 47, pp. 111-128, 2004.

[45] Argyelan, T., Díez, I., Vallés, M. \& Galiana, F., Land use change in Huerta de Valencia (2008-2013). Resilience and cultural landscapes. Irrigation, Society and Landscape. Tribute to Thomas F. Glick, eds. C. Sanchis-Ibor, G. Palau-Salvador, I. Mangue \& L.P. Martínez-Sanmartín, UPV: Valencia, pp. 910-923, Valencia: UPV, 2014.

[46] Iranzo, E., L'Horta de Valencia. Incertidumbre para un paisaje cultural ancestral. Atlas de los paisajes agrarios de España, ed. F. Molinero, Ministerio de Agricultura, Alimentación y Medio Ambiente: Madrid, pp. 513-532, 2014.

[47] Martínez, J., Lo que nos enseñan los regadíos tradicionales. Soberanía Alimentaria, Biodiversidad y Culturas, 14, pp. 21-25, 2013.

[48] Romero, J. \& Francés, M. (eds), La Huerta de Valencia. Un Paisaje Cultural con Futuro Incierto, PUV: Valencia, 2012.

[49] Zonneveld, W., de Vries, J. \& Janssen-Jansen, L. (eds), European Territorial Governance, IOS Press: Amsterdam, 2012.

[50] Official Journal of the European Union (OJEU), p. 62, 23 March 2005.

[51] Parc Agrari del Baix Llobregat, Agroterritori and Red Agroterritorial, Charter on Periurban Agriculture, http://www.agroterritori.org/web2/wp-content/uploads/2014/05/CHARTER_ON_PERIURBAN_AGRICULTURE.pdf, 2010 (accessed 5 December 2018).

[52] Romero, J. \& Farinós, J., Cities and urban and metropolitan regions in Spain: A new agenda in a global context. Urban Governance in Southern Europe, eds. J. Seixas \& A. Albet, Ashgate: Farnham, pp. 123-148, 2012.

[53] Romero, J., Melo, C. \& Brandos, D., The neoliberal model of the city in Southern Europe. A comparative approach to Valencia and Madrid. Cities in Crisis: Socio-Spatial Impacts of the Economic Crisis in Southern European Cities, eds. J. Knieling \& F. Othengrafen, Routledge: London, pp. 73-93, 2016.

[54] Romero, J. \& Melo, C., Spanish Mediterranean Huertas: Theory and reality in the planning and management of peri-urban agriculture and cultural landscapes. WIT Transactions on Ecology and the Environment, 193, pp. 585-595, 2015.

[55] Criado, A.M., La política de paisaje de la Comunitat Valenciana. Cuadernos Geográfi$\cos , \mathbf{4 3 ( 2 )}$, pp. 99-121, 2008.

[56] de Orueta, E.L.B., La planificación territorial en la Comunidad Valenciana (1986-2009), Scripta Nova. Revista electrónica de geografía y ciencias sociales, Vol. 13, 2009.

[57] Moreno, P., Valencia reserva cien hectáreas de huerta protegida para grandes proyectos privados, Las Provincias, http://www.lasprovincias.es/valencia-ciudad/201412/19/valencia-reserva-cien-hectareas-20141219013417-v.html, 19 December 2014 (accessed 6 April 2015).

[58] Vázquez, C., 20.000 alegaciones contra la pérdida de huerta en Valencia, El País, http://ccaa.elpais.com/ccaa/2015/02/24/valencia/1424806616_984606.html?rel=rosEP, 25 February 2015 (accessed 6 April 2015).

[59] García, H., La Universitat de València pide a Barberá que retire el PGOU y preserve la Huerta, Levante, http://www.levante-emv.com/valencia/2015/03/04/universitat-valencia-pide-barbera-retire/1233725.html, 4 March 2015 (accessed 6 April 2015). 
[60] Ros, M., Rodear Valencia en bicicleta para reivindicar la huerta. Levante, http://www. levante-emv.com/valencia/2015/03/13/rodear-valencia-bicicleta-reivindicar-huerta/1237734.html, 13 March 2015 (accessed 6 April 2015).

[61] Generalitat Valenciana, Llei 5/2018, de 6 de març, de la Generalitat, de l'Horta de València, http://www.habitatge.gva.es/documents/20551069/165095422/Ley+5-2018\%2C\%20 de+6+de+marzo $\% 2 \mathrm{C} \% 20 \mathrm{de}+\mathrm{la}+$ Generalitat $\% 2 \mathrm{C} \% 20 \mathrm{de}+\mathrm{la}+\mathrm{Huerta}+\mathrm{de}+\mathrm{Val} \% \mathrm{C} 3 \% \mathrm{~A} 8 \mathrm{n}$ cia/6002e462-b64e-4c0b-83c9-f856b246deab (accessed 1 December 2018).

[62] Generalitat Valenciana, PAT Horta de València, http://www.habitatge.gva.es/web/planificacion-territorial-e-infraestructura-verde/pat-horta-de-valencia (accessed 1 December 2018).

[63] Simón Rojo, M., Zazo Moratalla, A. \& Morán Alonso, N., Nuevos enfoques en la planificación urbanística para proteger los espacios agrarios periurbanos. Ciudades, 15(1), pp. 151-166, 2012. https://doi.org/10.24197/ciudades.15.2012.151-166

[64] Zasada, I., Multifunctional peri-urban agriculture: A review of societal demands and the provision of goods and services by farming. Land Use Policy, 28(4), pp. 639-648, 2011. https://doi.org/10.1016/j.landusepol.2011.01.008

[65] Gómez-Limón, J.A., Barreiro, J., Mármol, E. \& Marcos, C. (eds), La Multifuncionalidad de la Agricultura en España, Eumedia: Madrid, 2007.

[66] Bomans, K., Steenberghen, T., Dewaelheyns, V., Leinfelder, H. \& Gulinck, H., Underrated transformations in the open space - the case of an urbanized and multifunctional area. Landscape and Urban Planning, 94(3-4), pp. 196-205, 2009. https://doi. org/10.1016/j.landurbplan.2009.10.004

[67] Brandt, J. \& Vejre, H., Multifunctional landscapes - motives, concepts and perspectives. Multifunctional Landscapes, Volume I-Theory, Values and History, eds. J. Brandt \& H. Vejre, WIT Press: Southampton, pp. 3-31, 2004.

[68] Paül, V. \& McKenzie, F.H., Peri-urban farmland conservation and development of alternative food networks: Insights from a case-study area in metropolitan Barcelona (Catalonia, Spain). Land Use Policy, 30(1), pp. 94-105, 2013. https://doi.org/10.1016/j. landusepol.2012.02.009

[69] Giacché, G. \& Mazzocchi, C., Gli instrumenti de pianificazione territoriale in relazione alla funcionalità dell'agricoltura periurbana, Projet de paysage, p. 21, www.projetsdepaysage.fr, 2011 (accessed 2 January 2015).

[70] Vidal, R. \& Fleury, A., La place de l'agriculture dans la metropole verte. Nostalgies, utopies et realités dans l'aménagement des territoires aux franges urbaines, Projet de paysage, p. 15, www.projetsdepaysage.fr, 2009 (accessed 2 January 2015).

[71] Stanners, D. \& Bourdeau, P. (eds), Europe's Environment: The Dobris Assessment, European Environmental Agency: Copenhagen, 1995. 